\title{
Expression of Genes Involved in Glycolytic Pathway Upon Glucose Limitation in Leukemia Cells
}

\section{Lösemi Hücrelerinde Glukoz Kısıtlamasında Glikolitik Yolaktaki Genlerin Ekspresyonu}

\section{Burcu YUCEL $\odot$, Sedef ALTUNDAG KARA $\odot$, Saniye ADA $\odot$, Berna DEMIRCAN TAN $\odot$}

Ethics Committee Approval: Not Applicable.

Conflict of interest: The authors declare that they have no conflict of interest.

Funding: This study funded by the Scientific and Technological Research Council of Turkey (TÜBITAK)

with the grant number of 217S792.

Informed Consent: Not Applicable.
Cite as: Yucel B, Altundag Kara S, Demircan Tan B. Expression of Genes Involved in Glycolytic Pathway Upon Glucose Limitation in Leukemia Cells. Medeniyet Med J. 2019;34:143-8.

\begin{abstract}
Objective: Leukemia is the cancer of hematopoietic system and is characterized by abnormal proliferation of blood precursor cells. Leukemia cells as other cancer cells multiply rapidly and they have increased nutrient needs. The most commonly used nutrient by cancer cells is glucose and therefore it is hypothesized that glucose is present at a low level in the microenvironment of cancer cells. Metabolic changes in leukemia cells due to nutrient deficiency add extra liabilities to the cells. In recent studies, increased glycolysis and reprogrammed glucose metabolism have been shown in different tumors Intermediate steps of glycolysis involving hexokinase, phosphofructokinase, pyruvate dehydrogenase kinase and lactate dehydrogenase enzymes are rate-limiting steps in the reaction and increased expressions were correlated with poor prognosis of leukemia.The aim of this study is to investigate the expression of glycolytic genes in low glucose conditions.

Method: In this study, we control expression of rate-limiting glycolytic enzymes' mRNA expressions in K562, NB-4 and $\mathrm{HL}-60$ cell lines in low glucose (1 $\mathrm{mM}$ ) concentration compared to normal $(10 \mathrm{mM})$ concentration using $q R T-P C R$ assay.

Results: We found that PKM2 and LDHA mRNA expressions were significantly decreased in low glucose conditions. On the other hand, HK1 and HK2 expressions were increased in $K 562$ cells $(p<0.001)$. We also found that PFKL expression was decreased in $K 562$ cells.

Conclusion: Our results show that targeting glucose metabolism can reduce expression of glycolytic genes and therefore in compliance with the literature suggest that glucose metabolism may be a target in the treatment of leukemia.
\end{abstract}

Keywords: Leukemia, cancer metabolism, glycolysis, gene expression

\section{Öz}

Amaç: Lösemi, hematopoetik sistemin kanseridir ve kan öncül hücrelerinin anormal proliferasyonu ile karakterizedir. Diğer kanser hücreleri gibi lösemi hücreleri de hızla çoğalır ve artmıs besin gereksinimleri vardır. Kanser hücreleri tarafindan en yaygın olarak kullanılan besin maddesi glukozdur ve bu nedenle kanser hücrelerinin çevresinde düşük seviyede glukozun bulunduğu varsayılmaktadır. Lösemi hücrelerine besin eksikliği meydana gelen metabolik değişiklikler nedeniyle ekstra sorumluluk katar. Son zamanlarda yapılan çalışmalarda, farklı tümörlerde artmış glikoliz ve yeniden programlanmış glukoz metabolizması gösterilmiştir. Heksokinaz, fosfofruktokinaz, piruvat dehidrojenaz kinaz ve laktat dehidrojenaz enzimlerini içeren glikoliz ara adımları reaksiyonda hız sınırlayıcı adımlardır ve artan ekspresyonları löseminin zayıf prognozu ile iliş̧ilendirilmiştir. Bu çalışmanın amacı, düşük glukoz konsantrasyonlarında glikolizde rol alan genlerin ekspresyonlarını araștırmaktır.

Yöntem: Bu çalışmada, normal (10 mM) ortama kıyasla düşük glukozlu (1 mM) ortamda, $K 562$. $N B-4$ ve $H L-60$ hücre hatlarında hız sınırlayıc glikolitik enzimlerin mRNA ifadelerini qRT-PCR ile kontrol ettik.

Bulgular: PKM2 ve LDHA mRNA ifadelerinin düşük glukoz koșullarında önemli ölçüde azaldığını bulduk. Öte yandan, HK1 ve HK2 mRNA'ları ise K562 hücrelerinde artmıştır ( $p<0.001)$. K562 hücrelerinde PFKL ekspresyonunun azaldığını da bulduk.

Sonuç: Sonuçlarımız, glukoz metabolizmasının hedeflenmesinin glikolitik genlerin ekspresyonunu azaltabileceğini ve dolayısıyla glukoz metabolizmasının lösemi tedavisinde bir hedef olabileceğini göstermektedir.

Anahtar kelimeler: Lösemi, kanser metabolizması, glikoliz, gen ekspresyonu
Received: 24.04 .2019

Accepted: 10.05 .2019

Online First: 10.06 .2019

Corresponding Author: B. Yucel

ORCID: 0000-0002-6599-4558 Istanbul Medeniyet University, Medical Faculty,

Department of Medical Biology, İstanbul - Turkey

burcu.yucel@medeniyet.edu.tr S. Altundag Kara

S. Ada

ORCID: 0000-0003-4927-6625

Istanbul Medeniyet University,

Medical Faculty, Department of Medical Biochemistry, Istanbul, Turkey

B. Demircan Tan

ORCID: 0000-0001-9910-8713 Istanbul Medeniyet University, Medical Faculty, Department of Medical Biology, Istanbul, Turkey 


\section{INTRODUCTION}

Cancer is a complex disease in which cells proliferate in an uncontrolled manner as a result of genetic changes. Additionally, cells phenotypically change and many cellular pathways including metabolism are rewired ${ }^{1}$. Leukemia is a malignant disease of the hematopoietic system and is characterized by abnormal proliferation of blood precursor cells ${ }^{2}$. As cancer cells multiply rapidly, they have increased nutrient needs and quickly consume nutrients in the surrounding environment ${ }^{3}$. Even hematopoietic tumors, such as leukemia, are not an exception to this rule. The most commonly used nutrient by cancer cells is glucose and therefore it is hypothesized that glucose is present at a low level in the microenvironment of cancer cells. Metabolic changes in leukemia cells due to nutrient deficiency add extra liabilities to the cells ${ }^{4}$.

Glycolysis is a series of biochemical reactions that lead to the conversion of glucose into pyruvate. The glycolytic intermediates produce different biosynthetic precursors during the reactions. It is well known that cancer cells provide the necessary bioenergetics by converting glucose into lactate even in the presence of oxygen, and this phenomenon is known as 'Warburg effect' ${ }^{\text {'. In re- }}$ cent studies, increased glycolysis and reprogrammed glucose metabolism have been shown in different tumors ${ }^{6}$. The relation between oncogenic mutations and the metabolic changes occurring in leukemia cells is an ongoing research topic.

Studies with different tumor cells have shown that a group of cells continue to proliferate in low concentrations ${ }^{7}$. To know how adaptive mechanisms are carried out in order to maintain the survival and proliferation of cancer cells in low nutrient level environment is thought to contribute to diagnosis and therapy as well as identification of new drug targets for drug resistant cancer subtypes $^{8}$. Indeed, it has been reported that in diverse subtypes of leukemia, the glycolytic mechanisms and the response to glucose restriction differ ${ }^{9}$. In addition, high glycolytic metabolism of leukemia cells makes these cells excellent assay models for metabolic regulation studies.

Intermediate steps in glycolysis involving hexokinase (HK1, HK2) phosphofructokinase (PFKP, PFKL) pyruvate dehydrogenase kinase (PKM2) and lactate dehydrogenase enzymes (LDHA and LDHB) are rate-limiting steps of the reaction. The increase in the expressions of mRNA isoforms of the genes encoding these enzymes has been associated with poor prognosis in different subtypes of leukemia ${ }^{10,11}$.

In this study, we aimed to investigate the changes in mRNA expression of the genes involving in the glycolic pathway in leukemia cells during glucose restriction. Thus, we aimed to obtain data on metabolic adaptations of leukemia cells to changes in mRNA that may occur in the medium with low glucose concentration.

\section{MATERIALS and METHODS}

\section{Cell Culture}

K562, NB-4 and HL-60 cell lines were used in this study. All cell lines were grown in RPMI 1640 (Gibco) medium containing 10\% FBS (Sigma), $1 \%$ penicillin/streptomycin (Sigma) and 1\% L-glutamine at $37^{\circ} \mathrm{C}$ in $\% 5 \mathrm{CO}_{2}$.

For low glucose conditions RPMI 1640 w/o glucose, w/o glutamine medium (PAN) prepared with either $1 \mathrm{mM}$ or $10 \mathrm{mM}$ glucose concentrations.

\section{Glucose limitation experiments}

Cells seeded at a 20.000 cells $/ \mathrm{ml}$ concentration in a 6 well plate either in $10 \mathrm{mM}$ in $1 \mathrm{mM}$ glucose containing medium and cultured for 3 days at 5\% $\mathrm{CO}_{2}$ with atmospheric $\mathrm{O}_{2}$ at $37^{\circ} \mathrm{C}$.

\section{RNA isolation and cDNA synthesis}

Cells were collected at the end of the experiment and RNAs were isolated using RNeasy Plus RNA isolation kit (Qiagen), according to the 
manufacturer's instructions. RNA concentrations were measured and $1 \mu \mathrm{g}$ RNA sample was reverse transcribed using High-Capacity RNA-to-cDNA Kit (Applied Biosystems).

\section{QRT-PCR}

List of primers used in this study are given in Table 1. qRT-PCR reactions were carried on RotorGene (Qiagen) instrument using SYBR $®$ Green PCR Master Mix (Applied Biosystems). Ct results were normalized to RPLPO housekeeping gene. Relative mRNA fold changes were calculated using

Table 1. List of primers.

\begin{tabular}{|c|c|c|}
\hline Gene & & Sequence \\
\hline \multirow[t]{2}{*}{ RPLPO } & Forward & AGCATCTACAACCCTGAAGTG \\
\hline & Reverse & AGCAAGTGGGAAGGTGTAATC \\
\hline \multirow[t]{2}{*}{ LDHA } & Forward & AGGACTTGGCAGATGAACTTG \\
\hline & Reverse & CTTTCTCCCTCTTGCTGACG \\
\hline \multirow[t]{2}{*}{ LDHB } & Forward & CAGATCGTCAAGTACAGTCCTG \\
\hline & Reverse & TCAGCCATAAGGTAGCGAAATC \\
\hline \multirow[t]{2}{*}{ HK1 } & Forward & ACATTGTCTCCTGCATCTCTG \\
\hline & Reverse & GCCTTAAAACССТTTGTCCAC \\
\hline \multirow[t]{2}{*}{ HK2 } & Forward & GGGACAATGGATGCCTAGATG \\
\hline & Reverse & GTTACGGACAATCTCACCCAG \\
\hline \multirow[t]{2}{*}{ PFKP } & Forward & CATCGACAATGATTTCTGCGG \\
\hline & Reverse & ССАТСАССТССАGAACGAAG \\
\hline \multirow[t]{2}{*}{ PFKL } & Forward & AACGAGAAGTGCCATGACTAC \\
\hline & Reverse & GTCCCATAGTTCCGGTCAAAG \\
\hline \multirow[t]{2}{*}{ PKM2 } & Forward & AAGTGTGACGAGAACATCCTG \\
\hline & Reverse & АССАТTTTCСАССТССGТС \\
\hline
\end{tabular}

$\Delta \Delta \mathrm{Ct}$ method.

\section{Statistical analysis}

All experiments were repeated 3 times. RT-PCR reactions were carried out in triplicates. Student's $t$ test was applied to compare fold changes. Graphics were prepared in GraphPad Prism V6 software.

\section{RESULTS}

\section{HK-1 and HK-2 mRNA expressions}

HK-1 and HK-2 mRNA expressions increased in K562 and HL-60 cells, in $1 \mathrm{mM}$ glucose condition (low glucose condition) (Figure 1). In K562 cells, expressions increased almost 1.5 fold $(p<0.001)$. Although increase in HK-1 expression in HL-60 cells seems to be quite higher in low glucose, both the increase in HK-1 and HK-2 mRNA expressions were not statistically significant. On the other hand, in NB-4 cells, both HK-1 and HK-2 mRNA expressions dramatically decreased in low glucose conditions $(p<0.01)$.

\section{PFKL and PFKP expressions}

PFKL mRNA expression was decreased in all cell lines in low glucose conditions (Figure 2). However, the change was statistically significant only for $\mathrm{K} 562$ cells $(p<0.01)$. On the other side, we fo-
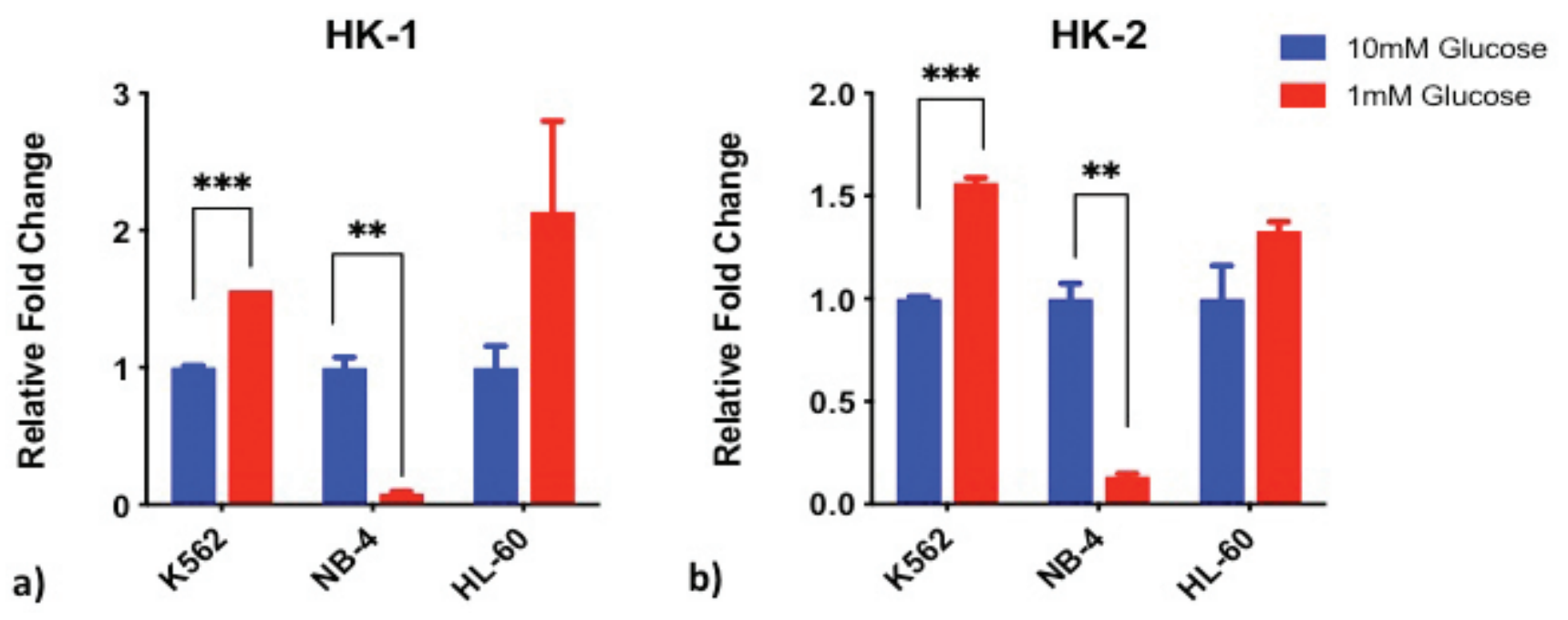

Figure 1. a) HK1 and b) HK2 mRNA expressions in K562, NB-4 and HL-60 cell lines in low glucose (1 mM) medium compared to normal conditions. Data presented as mean \pm SD. ${ }^{* *} p<0.001,{ }^{* * *} p<0.0001$. 
PFKL

옫

a)

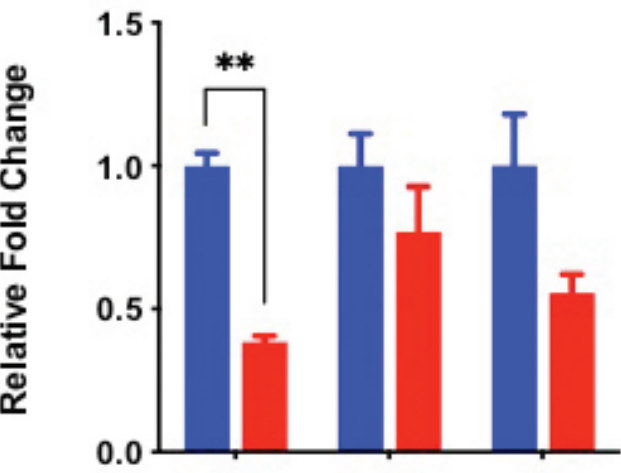

b)

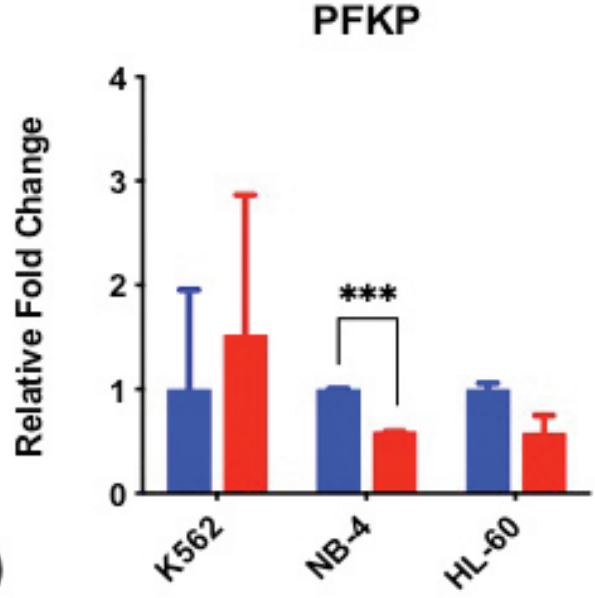

$10 \mathrm{mM}$ Glucose

$1 \mathrm{mM}$ Glucose

Figure 2. a) PFKL and b) PFKP mRNA expressions in K562, NB-4 and HL-60 cell lines in low glucose (1 mM) medium compared to normal conditions. Data presented as mean \pm SD. ${ }^{* *} \mathbf{p}<0.001,{ }^{* * *} \mathbf{p}<0.0001$.

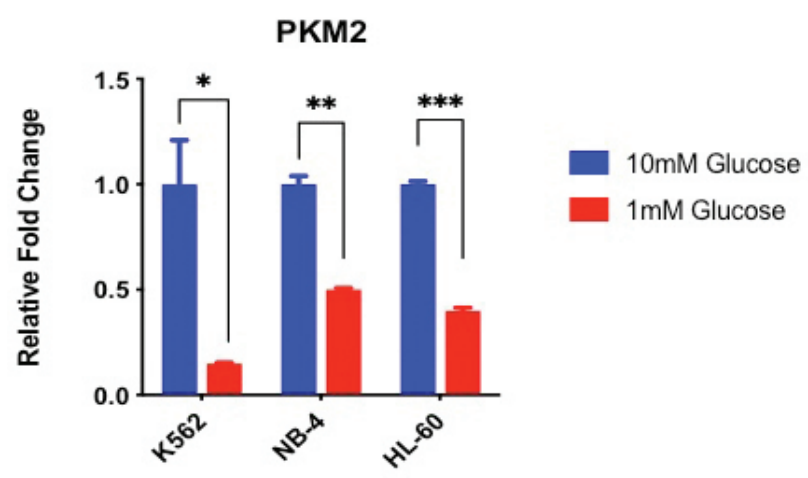

Figure 3. PKM2 mRNA expression in K562, NB-4 and HL-60 cell lines in low glucose $(1 \mathrm{mM})$ medium compared to normal conditions. Data presented as mean \pm SD. * $\mathbf{p}<0.005,{ }^{* *} \mathbf{p}<0.001,{ }^{* * *} \mathbf{p}<0.0001$. und that PFKP expression decreased only in NB-4 cells, significantly $(p<0.001)$. In K562 cells, though not statistically significant PFKP expression was increased in low glucose condition

\section{PKM2 expression}

PKM2 expression was decreased in all cell lines in low glucose conditions compare to normal medium (Figure 3). In K562 cells, PKM2 expression was lowered to almost 0.3 fold $(p<0.05)$. In NB-4 and HL-60 cell lines, PKM2 expression was down to half in $1 \mathrm{mM}$ glucose $(p<0.01$ and $p<0.001$, respectively).
LDHA

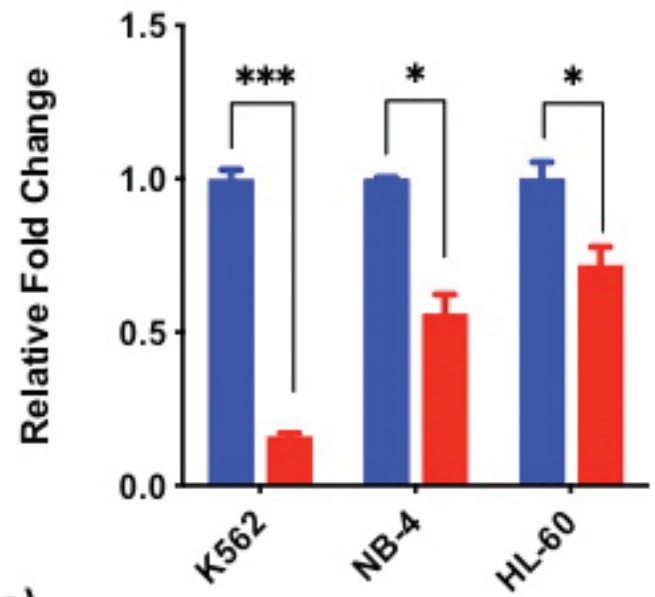

a)

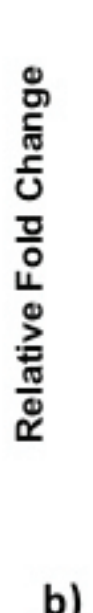

b)
LDHB

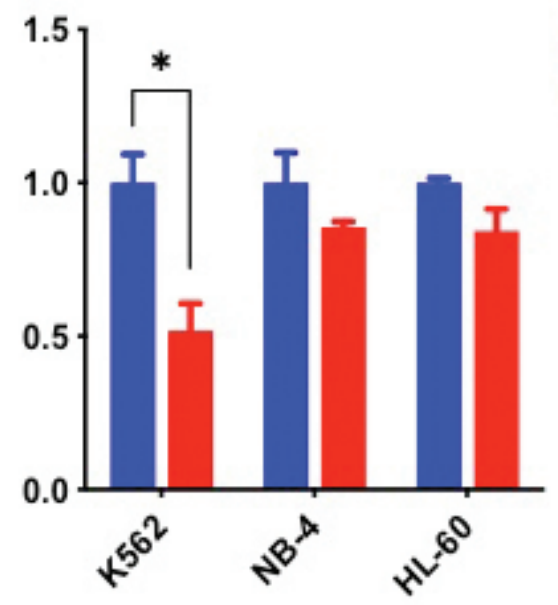

Figure 4. a) LDHA and b) LDHB mRNA expressions in K562, NB-4 and HL-60 cell lines in low glucose (1 mM) medium compared to normal conditions. Data presented as mean \pm SD. ${ }^{*} \mathbf{p}<0.005,{ }^{* *} \mathbf{p}<0.001,{ }^{* * *} \mathbf{p}<0.0001$. 


\section{LDHA and LDHB expressions}

Both LDHA and LDHB expressions were decreased in all cell lines in low glucose medium (Figure 4). In K562 cells, the decrease in LDHB expression was statistically significant $(p<0.05)$, but not in NB-4 and HL-60 cell lines. LDHA expression was lowered in low glucose in all cells, significantly $(p<0.001, p<0.05$ and $p<0.05$, respectively).

\section{DISCUSSION}

Cancer cells demand more nutrients to survive and multiply as they require more energy and biomolecules $^{12}$. Cancer cells have increased glucose uptake and they break down glucose by glycolysis independent from the amount of oxygen in the environment. This phenomenon, also known as aerobic glycolysis or Warburg effect, is one of the well-known mechanisms of cancer cell metabolism ${ }^{13}$. As a result of increased nutritional needs, it has been proposed that cancer cells have low level of nutrients in tumor microenvironment ${ }^{3}$. Knowing how adaptive mechanisms are carried out in order to maintain the survival and proliferation of cancer cells in low nutrient environment will contribute to diagnosis and treatment of cancer as well as determining new drug targets ${ }^{7}$. However, it is very difficult to mimic in vivo environment within in vitro cell culture conditions.

In a study conducted with glioblastoma cell lines, it was determined that cell viability decreased in low glucose environment ${ }^{14}$. It was shown that leukemia cell lines NB-4 and HL-60 have reduced cell viability upon inhibition of glycolysis and gain viability after addition of glucose to the medium $^{15}$.

In this study, we grow K562, NB-4 and HL-60 leukemia cell lines in low $(1 \mathrm{mM})$ and normal $(10 \mathrm{mM})$ glucose-containing media and isolated mRNAs. Expressions of PFKL, PFKP, PKM2, LDHA and LDHB mRNAs were controlled by qRT-PCR.

We found that HK1 and HK2 mRNA expressi- ons increased in $\mathrm{K} 562$ and HL-60 cells, whereas decreased in NB-4 cells in low glucose medium. However, the change in HL-60 cells was not statistically significant. In a study in which different leukemia cell lines were used, the expression of genes on the glycolytic pathway was shown to be at different levels ${ }^{9}$. It was shown that suppression of HK1 and HK2 with shRNAs, render cells more sensitive to Ara-C treatment ${ }^{9,16}$.

Pyruvate kinase muscle type (PKM2) enzyme is encoded by PKM gene and catalyzes the last step of glycolysis. This step is irreversible and one of the 'limiting' stages in glycolysis. The increased expression of PKM2 in the vast majority of cancer cells suggests that it could be a target for anticancer treatments ${ }^{17}$. Recently, proteins in which PKM2 interacts with and play a role in tumor metabolism and growth have also gained importance. In glioblastoma cell lines, a decrease in PKM2 mRNA expression was observed by suppression of GLUT3 with siRNA ${ }^{14}$. In a study with pancreatic cancer cells, the inhibition of PKM2 expression in the normal glucose medium did not affect cell growth and proliferation, whereas the suppression of PKM2 expression in low glucose $(0.5 \mathrm{mM})$ medium increased cell viability ${ }^{18}$. In another study with lung cancer cells, it was determined that induced PKM2 mRNA expression in low glucose medium increased cell proliferation ${ }^{19}$. In our study, we found that PKM2 expressions decreased significantly in low glucose medium in all cell lines we used.

In our study, we also showed that PFKL expression was lowered in $\mathrm{K} 562$ cell line and PFKP expression decreased in NB-4 cells in low glucose medium. While LDHA expression was decreased in all cells, LDHB expression was decreased only in $\mathrm{K} 562$ cells in low glucose medium. In a study, PFKP expression level was found higher in poor cytogenetic risk group of $A M L$ patients ${ }^{20}$. In a different study LDHA knockout cells slowed down leukemia progression compared with normal white blood cells ${ }^{21}$. 


\section{CONCLUSION}

To conclude, our results suggest that targeting glucose metabolism can reduce expression of glycolytic genes and therefore in compliance with the literature demonstrate that glucose metabolism may be a target in the treatment of leukemia. To further highlight this hypothesis, effect of inhibition of glycolytic genes in low glucose conditions should be studied and complemented with in vivo animal experiments.

\section{REFERENCES}

1. Hanahan D, Weinberg Robert A. Hallmarks of Cancer: The Next Generation. Cell. 2011;144:646-74. [CrossRef]

2. Döhner H, Weisdorf DJ, Bloomfield CD. Acute Myeloid Leukemia. N Eng J Med. 2015;373:1136-52. [CrossRef]

3. Birsoy K, Sabatini DM, Possemato R. Untuning the tumor metabolic machine: Targeting cancer metabolism: a bedside lesson. Nat Med. 2012;18:1022-3. [CrossRef]

4. Hauge $M$, Bruserud $\varnothing$, Hatfield KJ. Targeting of cell metabolism in human acute myeloid leukemia - more than targeting of isocitrate dehydrogenase mutations and PI3K/ AKT/mTOR signaling? Eur J Haematol. 2016;96:211-21. [CrossRef]

5. Vander Heiden MG, Cantley LC, Thompson CB. Understanding the Warburg Effect: The Metabolic Requirements of Cell Proliferation. Science. 2009;324:1029-33. [CrossRef]

6. Vander Heiden MG. Targeting cancer metabolism: a therapeutic window opens. Nat Rev Drug Discov. 2011;10:671-84. [CrossRef]

7. Sullivan LB, Gui DY, Heiden MGV. Altered metabolite levels in cancer: implications for tumour biology and cancer therapy. Nat Rev Canser. 2016;16:680-93. [CrossRef]

8. Liang H, Zheng QL, Fang P, et al. Targeting the PI3K/AKT pathway via GLI1 inhibition enhanced the drug sensitivity of acute myeloid leukemia cells. Sci Rep. 2017;7:40361. [CrossRef]
9. Chen WL, Wang JH, Zhao AH, et al. A distinct glucose metabolism signature of acute myeloid leukemia with prognostic value. Blood. 2014;124:1645-54. [CrossRef]

10. Le A, Lane AN, Hamaker $M$, et al. Glucose-independent glutamine metabolism via TCA cycling for proliferation and survival in B-cells. Cell Metab. 2012;15:110-21. [CrossRef]

11. Knoechel B, Aster Jon C. Metabolic Mechanisms of Drug Resistance in Leukemia. Cell Metab. 2015;22,759-60. [CrossRef]

12. DeBerardinis RJ, Lum JJ, Hatzivassiliou G, Thompson CB. The Biology of Cancer: Metabolic Reprogramming Fuels Cell Growth and Proliferation. Cell Metab. 2008;7:11-20. [CrossRef]

13. Heiden MGV, DeBerardinis RJ: Understanding the intersections between metabolism and cancer biology. Cell. 2017;168:657-69. [CrossRef]

14. Cosset É, Ilmjärv S, Dutoit V, et al.: Glut3 Addiction Is a Druggable Vulnerability for a Molecularly Defined Subpopulation of Glioblastoma. Cancer Cell. 2017;32:856-68. [CrossRef]

15. Suganuma K, Miwa H, Imai N, et al. Energy metabolism of leukemia cells: glycolysis versus oxidative phosphorylation. Leuk Lymphoma. 2010;51:2112-9. [CrossRef]

16. Xu S, Catapang A, Braas D, et al. A precision therapeutic strategy for hexokinase 1 -null, hexokinase 2-positive cancers. Cancer Metab. 2018;6:7. [CrossRef]

17. Christofk HR, Vander Heiden MG, Harris $M H$, et al. The M2 splice isoform of pyruvate kinase is important for cancer metabolism and tumour growth. Nature. 2008;452:230-3. [CrossRef]

18. Li X, Deng S, Liu M, et al. The responsively decreased PKM2 facilitates the survival of pancreatic cancer cells in hypoglucose. Cell Death Dis. 2018;9:133. [CrossRef]

19. Tee SS, Park JM, Hurd RE, et al. PKM2 activation sensitizes cancer cells to growth inhibition by 2-deoxy-D-glucose. Oncotarget. 2017;8:90959-68. [CrossRef]

20. Luo X, Zheng D, Zheng R, et al. The Platelet Isoform of Phosphofructokinase in Acute Myeloid Leukemia: Clinical Relevance and Prognostic Implication. Blood 2018; 132:5251. [CrossRef]

21. Le A, Cooper CR, Gouw AM, et al. Inhibition of lactate dehydrogenase $A$ induces oxidative stress and inhibits tumor progression. Proc Natl Acad Sci U S A. 2010;107:2037-42. [CrossRef] 